well within asteroidal limits. Of the twenty comets, not only have seven disappeared, but five, or, including Encke's and Biela's, seven, have periods commensurable with that of Jupiter ; all the twenty have direct motion; all but one have smaller inclination than Pallas; and, as with the asteroids, there is a tendency of the perihelia to concentrate in the $180^{\circ}$ from $290^{\circ}$ to $110^{\circ}$.

New Minor Planet. - A new minor planet was discovered by M. Borrelly on May 12 at Marseilles. This may possibly, but not very probably, prove to be Xanthippe, No. 156. Should it be reatly a fresh discovery, it will rank as No. 278 , whilst the one discovered by Herr Palisa on May 16 (see NATURE, vol xxxviii. p. 89) will be numbered 279 .

\section{ASTRONOMICAL PHENOMENA FOR THE WEEK 1888 JUNE 3-9.}

(FOR the reckoning of time the civil day, commencing at Greenwich mean midnight, counting the hours on to 24 is here employed.)

\section{At Greenwich on June 3}

Sun rises, $3^{\text {h. }} 49 \mathrm{~m}$.; souths, Ixh. $57 \mathrm{~m} .57^{\circ} 6 \mathrm{~s}$.; sets, $20 \mathrm{~h} .7 \mathrm{~m}$. : right asc. on meridian, $4 \mathrm{~h} .47^{\circ} 4 \mathrm{~m}$. ; decl. $23^{\circ} 24^{\prime} \mathrm{N}$. Sidereal Time at Sunset, $12 \mathrm{~h} .58 \mathrm{~m}$

Moon (New on June 9, I7h.) rises, Ih. 42m. ; souths, 7 h. 3om.; sets, $13 \mathrm{~h}$. $29 \mathrm{~m}$. : right asc. on meridian, oh. $18 \cdot 6 \mathrm{~m}$. ; decl. $2^{\circ} 54^{\prime} \mathrm{S}$.

Planet. Rises. Souths. Sets. Right asc. and declination

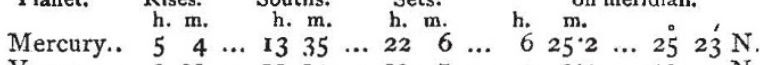
$\begin{array}{lllllllllllllllll}\text { Venus } & \ldots & 3 & 21 & \ldots & \text { II } & 14 & \ldots & 19 & 7 & \ldots & 4 & 3.4 & \ldots & 20 & 4 & \mathrm{~N}\end{array}$ $\begin{array}{lllllllllllllllllllllll}\text { Mars } & \ldots & 14 & 19 & \ldots & 19 & 57 & \ldots & 1 & 35^{*} \ldots & 12 & 47^{\circ} 6 & \ldots & 5 & 3 & \mathrm{~S} .\end{array}$ $\begin{array}{llllllllllllllllll}\text { Jupiter } & \ldots & 18 & 18 & \ldots & 23 & 0 & \ldots & 3 & 21^{*} & \ldots & 15 & 5 I^{\prime} 7 & \ldots & 19 & 12 & \mathrm{~S} .\end{array}$ $\begin{array}{lllllllllllllllllll}\text { Saturn } & \ldots & 7 & 38 & \ldots & 15 & 32 & \ldots & 23 & 26 & \ldots & 8 & 22 & 0 & \ldots & 20 & 5 & \mathrm{~N}\end{array}$

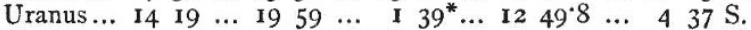
$\begin{array}{llllllllllllllllll}\text { Neptune.. } & 3 & 20 & \ldots & \text { II } & 5 & \ldots & 18 & 50 & \ldots & 3 & 53.9 & \ldots & 18 & 38 & \mathrm{~N} & \end{array}$ * Indicates that the rising is that of the preceding evening and the setting that of the following morning.

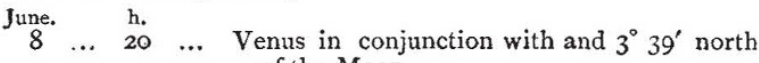
of the Moon.

Star.

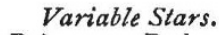

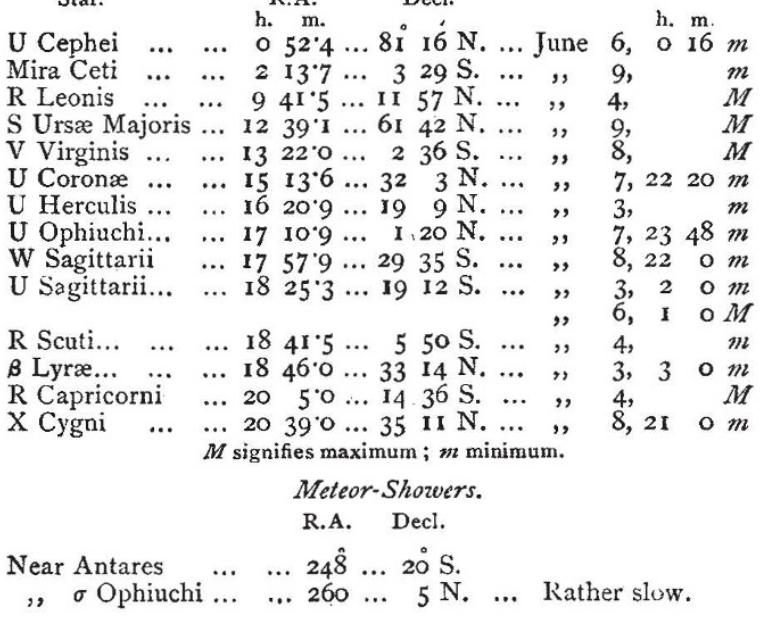

\section{GEOGRAPHICAL NOTES.}

IN the Report of the Survey of India for 1886-87, Colonel Strahan gives an account of the survey and exploration of the Nicobar Islands by himself and party. A very careful survey of the whole group was made, and the coast-lines at last accurately laid down. Owing to the dense vegetation, the party were unable to penetrate any distance into the interior, and only a few heights could be measured. The culninating point of the whole group, 2 I05 feet above sea-level, stands near the south-east corner of
Great Nicobar, the area of which is 375 square miles, the total area of the group being 678 square miles. The scenery, especially of Great and Little Nicobar, is of indescribable beauty. There are several rivers in the former island which are navigable by boats for some miles, especially the Galatea, on the south coast. Its course is very tortuous, the banks are fringed with tree-ferns, canes, bamboos, and tropical vegetation of infinite variety, through which occasional glimpses are obtained of high mountains in the interior covered with dense forests to their very summits, and generally cloud-capped. The country through which the stream runs is almost uninhabited; a few huts appear here and there tenanted by an inland tribe of savages called "Shom Pen," of whom very little is known, except that they are in such an utter state of barbarism as to be held in con. tempt even by the Nicobarese inhabiting the coasts. On most of the islands the forest grows luxuriantly down to the beach. Mangroves, except in the island of Kamorta, are not very plentiful, and in this respect these islands differ widely from the neighbouring Andaman group, where the creeks are fringed with mangroves mile after mile. The sea-beach consists largely of coral. The climate is very equable day and night all the year through, and most pleasant to one's feelings, but unfortunately its character for unhealthiness is only two well established. The rainfall, which averages about 100 inches, is pretty evenly distributed throughout the year. The thermometer stands very steadily between $80^{\circ}$ and $85^{\circ}$ in the shade, and hardly varies day or night. The inhabitants of these islands, Colonel Strahan states, are allied to the Malays, and are a complete contrast to their tiny, intensely black, woolly-haired neighbours the Andamanese. The Nicobarese are very strong, thickly built men, not much if at all inferior to Europeans in physique, of a reddish-brown colour. They are unconquerably lazy, having no inducement whatever to exertion. They have a wonderful talent for learning languages. Fortunately, Mr. Man, the Settlement Officer at Kamorta, who has done so much for Andaman anthropology, has been carefully studying the Nicobarese, their habits and language, and is now engaged on a book on the subject, which will shortly be published.

Mr. C. M. WOODFord, the successful naturalist explorer of the Solomon Islands, is about to leave England on a third visit to the group. After spending some time in various parts of the islands not previously visited, he will investigate Santa Cruz, Woodlark Island, and other islands lying to the south-east of New Guinea.

ACCORDING to the new Survey Report, triangulation surveys have already been effected over I5,000 square miles in Upper Burma, and the out-turn of reconnaissance surveys amounts to II,$\infty 0$ square miles on the scale of 4 miles to an inch, in the following States and districts : Northern Shan States and Ruby Mines district, 3000 square miles; Southern Shan States, 3000 ; Yemethin and Mehtila district, 2000; Yaw country, 1000; Mandalay and Kyaukse districts, 2000 .

IN the summary Report of the Geological Survey of Canada for 1887 , some of the results are given of the expedition under Dr. G. M. Dawson last summer, of the exploration of British Columbia. Mr. Ogilvie's instrumental survey to the intersection of the Yukon with the I4Ist meridian will form a sufficiently accurate base-line for future explorations in this region. In addition to this the geographical results include the completion of an instrumental survey of the Sitkine to Telegraph Creek by Mr. McConnell, which is connected with Dease Lake by a carefully placed traverse by Mr. M'Evoy. Thence a detailed runring survey was carried by the Dease, Liard, and Pelly Rivers, connecting with Mr. Ogilvie's line at the mouth of the Lewis River, a total distance of 900 mile:. Taken in conjunction with Mr. Ogilvie's line, these surveys include an area of over 6000 square miles, the interior of which is still, with the exception of reports received from a few prospectors and from Indians, a terra incognita. The same remark may be applied to the whole surrounding region outside the surveyed circuit, but much general information has been obtained respecting the entire district, which will facilitate further explorations. The whole region is more or less mountainous, though intersected by wide areas of flat or valley country. The country, though generally mountainous in character, includes large tracts of flat and slightly broken land, and, according to Dr. Dawson, may eventualiy support a population as large as that found in corresponding latitudes in Europe. 
THE anniversary meeting of the Royal Geographical Society was held on Monday in the hall of the University of London, General R. Strachey presiding. The report, which was read by Mr. Clements R. Markham, having been adopted, General Strachey was for the third consecutive year elected President of the Society. The Founder's Medal for the encouragement of geographical science and discovery was presented to $\mathrm{Mr}$. Clements R. Markham, who retires from the honorary secretary. ship after twenty-five years' service, in acknowledgment of the valiuable services rendered by him to the Society during that period. Lieut. H. Wissmann was awarded the Patron's Medal in recognition of his great achievements as an explorer in Central Africa; Mr. J. M'Carthy, Superintendent of Surveys in Siam, the Murchi-on Grant; Major Festing, the Cuthbert Peek Grant, for his services as a cartographer on the Gambia River and the country in the neighbourhood of Sierra Leone. The Gill Memorial for I 888 was secured by Mr. Charles M. Doughty. Various scholarships and prizes to students in training colleges were also distributed. The President then delivered his annual address, passing in review the chief geographical events of the year.

\section{THE LINNEAN SOCIETY.}

THE hundredth anniversary mseting of this Society was held on Thursday last, 24th inst., at Burlington House, in the library, the usual meeting-room being inadequate for the reception of the large number of members present on this occasion. The President, Mr. Wm. Carruthers, F.R.S., took the chair at three o'clock, and was supported by the two former Presidents who are happily still with us-Prof. Allman and Sir John Lubbockthe Council of the Society, and many distinguished Fellows, amongst whom we noted Sir Richard Owen, Sir Joseph Hooker, Dr. Giinther, Sir Walter Buller, Prof. Duncan, Mr. Romanes, Colon-1 Grant, and amongst the visitors Dr. Henry Woodward, F.R.S., and Mr. Studiey Martin, a nephew of the founder.

After preliminary business, H.M. the King of Sweden was elected an honorary member. The Treasurer, Mr. Frank Crisp, laid the last year's accounts before the meeting, and briefly referred to the financial history of the Society during the century now closed. The senior Secretary, Mr. B. Daydon Jackson, presented an account of the Linnean collections from their formation, their purchase by the fcunder of the Society, and their possession by the Linnean Society. This was succeeded by the President's annual address, which was largely devoted to a review of the Society's past career. He spoke of the original quarto Transactions, then of the octavo Proceedings, finally of the Journal, of which forty-three volumes are extant. During the past year seven parts of the Transactions and twenty of the Journal had been issued, an amount equal to that published during fifteen years in the early part of the century.

A novel feature was then introduced, one of those intended to mark the centenary of the Society. Prof. Thöre Fries, the present occupant of Linnæus's Botanical Chair at Upsala, had been irvited to pronounce a eulogium on his illustrious predecessor. As he was detained by his professorial duties in his University, his essay was read by the President. In it he spoke of the profound sleep of natural science during the Middle Ag, s, and the hard struggle which had to be fought before men of science could liberate themselves from a narrow orthodoxy, or the fetters they had themselves forged by attaching infallibility to Aristotle and classic authors. Linnæus bore an honourable part in placing the study of natural science on a logical basis by his clear definitions, and admirable nomenclature, and by the enthusiasm he was able to rouse in his disciples for the same methods. England, unluckily for Sweden, became his heir; many consequently are the ties which unite the memory of Linnæus with this country, the strongest perhaps being the Linnean spirit, the genuine spirit of freshness and enterprise in which scientific research is carried on in England.

Sir Joseph Hooker then pronounced a eulogy on Robert Brown, the greatest botanist of the present century. $\mathrm{He}$ specially dwelt on the evidence affurded by the "Prodromus" of his untiring industry, accuracy of observation and exposition, together with sagacity, caution, and soundness of judgment, in which he has not been surpassed. Where others have advanced beyond the goal he reacied, it has been by working on the foundations he laid, aided by modern appliances of optics and physics. His memory was wonderful, he seemed never to forget a plant he had examined; and the same with his books- he could turn to descriptions for a statement or a figure without needing a reference. The noble title conferred upon him by Humboldt has been confirmed by acclamation by botanists of every country, "Botanicorum facile princeps."

Prof. Flower, C.B., F.R.S., delivered an address on Charles Darwin, who, he said, had special claims on their consideration, inasmuch as a large and very important portion of his work was communicated to the world by papers read before the Society and published in the Journal. His life was one long battle against our ignorance of the mysteries of living Nature, and he sought to penetrate the shroud which conceals the causes of all the variety and wonders round us His main victory was the destruction of the conception of species as being fixed and unchangeable beyond certain narrow linits, a view which prevailed universally before his time. That other factors had operated besides natural selection in bringing about the present condition of the organic world was admitted even by Darwin himself. His work, and the discussions which had sprung from it, had marvellously stimulated research, and he had shown by his life and labours the true methods by which alone the secrets of Nature may be won.

Prof. W. T. Thiselton Dyer spoke on George Bentham, who presided over the Society from 1863 to 1874 . A nephew of Jeremy Bentham, and trained to some extent under him, he was early imbued with a taste for method and analysis, and through his mother's fondness for plants he was led to study them, with marvellous results. The records of his life-work are astonishing. Whilst President he delivered a series of masterly addresses, and the latter part of his career witnessed the pre. paration of the "Flora Australiensis" and a full share of the "Genera Plantarum." He stood in the footsteps of Linnæus, and although the descent was oblique he inherited the mantle of the master whose memory was that day commemorated.

The President stated that the Council had decided to establish a Linnean Gold Medal, to be presented to a botanist and a zoologist in alternate years, but on this occasion it would be awarded in duplicate. The medal bore on the obverse a profile of Linnaus, modelled from the bust in the library; on the reverse, the arms of the Society and the name of the recipient. The President made the first presentation to Sir Richard Owen, recounting the chief services he had rendered to zoology. Sir Richard, with some emotion, expressed his high sense of the honour conferred, and thanked the Fellows for their cordial reception of him. The President then presented a similar medal to Sir Joseph Hooker, with a like recapitulation of the splendid services he had bestowed on botany. Sir Joseph suitably replied, returning his cordial thanks for the distinction.

The remaining formal business included the announcement of the newly-elected Councillors, and the re-election of the officers-Mr. Wm. Carruthers, President; Mr. Frank Crisp, Treasurer; and Messrs. B. Daydon Jackson, and W. Percy Sladen, Secretaries.

The annual dinner was held at the Hotel Victoria, Northum. berland Avenue, at seven o'clock. The President took the chair, about sixty of the Fellows being present. In addition to the usual toasts, that of "The Medallists" was given, and replied to by Sir Joseph Hooker, who alluded to the fact that he had personally known eight of the Presidents of the Society, and that the founder himself induced his father, Sir William Hooker, to take up the study of botany. As a proof of his close connection with the Linnean Society, he added that his father, grandfather, father-in-law, and uncle had all been Fellows.

The final portion of the centenary celebration took place the following evening, when the President and officers held a reception at Burlington House. A special feature was made of the Linnean manuscripts and memorials, which were displayed in glass cases with descriptions, a catalogue of them being also distributed. Memorials of other distinguished naturalists were also shown, conspicuously those of Robert Brown and George Bentham, lent by Sir Joseph Hooker and M. Alphonse de Candolle, of Geneva, a foreign member of the Society.

\section{UNIVERSITY AND EDUCATIONAL} INTELLIGENCE.

CAmbridge. - The Rede Lecture on June 8, by Sir F. A. Abel, will be upon applications of science to the protection of human life. It will be illustrated by experiments and the exhibition of appliances. 